
EDITOR

Donald T. Critchlow

Arizona State University

\section{ASSOCIATE EDITOR}

David B. Robertson

University of Missouri, St. Louis

MANAGING EDITOR

Patricia E. Powers

COPYEDITOR

Cherene Holland

EDITORIAL BOARD

Paula Baker (History)

The Ohio State University

Brian Balogh (History)

University of Virginia

Richard Bensel (Government)

Cornell University

Eileen Boris (Feminist Studies)

University of California, Santa Barbara

W. Elliot Brownlee (History)

University of California, Santa Barbara

Vincent Cannato (History)

University of Massachusetts, Boston

Christy Ford Chapin (History)

University of Maryland, Baltimore County

Daniel DiSalvo (Political Science)

City University of New York

Robin Einhorn (History)

University of California, Berkeley

David Farber (History)

University of Kansas
Richard R. John (Journalism)

Columbia University

Ira Katznelson (Political Science)

Columbia University

Matthew Lassiter (History)

University of Michigan

Christopher Loss (History)

Vanderbilt University

William Lowry (Political Science)

Washington University, St. Louis

Paul Milazzo (History)

Ohio University

James Mohr (History)

University of Oregon

Byron E. Shafer (Political Science)

University of Wisconsin, Madison

Bartholomew Sparrow (Government)

University of Texas, Austin

Ann-Marie Szymanski (Political Science)

University of Oklahoma

Alan Ware (Politics)

Oxford University 
JOURNAL OF POLICY HISTORY

articles

MICHAEL LEWIS $\quad 385$

From Prohibition to Liquor Dispensaries: Explaining the Rise and Fall of State and Municipal Liquor Stores, 1891-1907

TERESA SABOL SPEZIO 412

"An Inevitable Consequence:" Changing Ideas of

Prevention in the Wake of Catastrophic Events

ANDRÉS SPOGNARDI 439

Cooperatives as a Buffer Between Capitalism's Conflicting

Classes: The Pioneering Case of the Portuguese

Cooperative Societies Act

critical perspective

MAGNUS LINNARSSON AND MATS HALLENBERG

The Shifting Politics of Public Services: Discourses, Arguments, and Institutional Change in Sweden,

c. $1620-2000$

CONTRIBUTORS

487

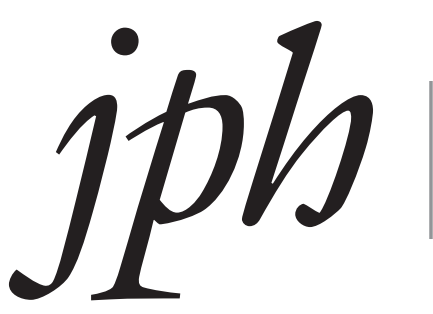

VOL. 32 NO. 4

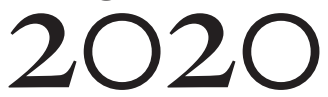


Subscription Information: The Journal of Policy History (ISSN: 0898-0306) is published quarterly by Cambridge University Press. Annual subscription rates for Volume 32 (2020): Institutional subscription rates, print and online: US $\$ 258.00$ in the USA, Canada, and Mexico; $£ U K 151.00+V A T$ elsewhere. Institutional subscription rates, online only: \$197.00 in the USA, Canada, and Mexico; £UK $114.00+$ VAT elsewhere. Individual subscription rates, print and online: $\$ 69.00$ in the USA, Canada, and Mexico; $£$ UK 40.00 + VAT elsewhere. Institutional subscription correspondence should be sent to: Cambridge University Press, One Liberty Plaza, 20th floor, New York, NY 10006 USA, for customers in the USA, Canada, or Mexico. Customers elsewhere should contact Cambridge University Press, University Printing House, Shaftesbury Road, Cambridge CB2 8BS, UK.

POSTMASTER: Send address changes in the USA, Canada, and Mexico to: Journal of Policy History, Cambridge University Press, Journals Fulfillment Department, One Liberty Plaza, 20th Floor, New York, NY 10006. Send address changes elsewhere to: Journal of Policy History, Cambridge University Press, Journals Fulfillment Department, One Liberty Plaza, 20th Floor, New York, NY 10006.

Abstract and Indexing Services: The journal is submitted to the following for indexing: P.A.I.S. International, Humanities Abstracts, Institute for Scientific Information, University Microfilms Inc., Sage Publications, Sociological Abstracts, Historical Abstracts, and IBZ-International Bibliography of Periodical Literature.

Copyright (@ 2020 All rights reserved. No part of this publication may be reproduced, in any form or by any means, electronic, photocopying, or otherwise, without permission in writing from Cambridge University Press. Permission enquiries from the USA, Mexico, and Canada should be addressed to the New York office ofCambridge University Presshttp://www.cambridge.org/us/information/rights/contacts/newyork.htm; permission enquiriesfrom elsewhere shouldbeaddressed to theCambridgeofficehttp://www.cambridge.org/uk/ information/rights/contacts/cambridge.htm; permission enquiries from Australia and New Zealand should be addressed to the Melbourne office http://www.cambridge.org/aus/information/contacts_melbourne.htm.

Photocopying Information (for users in the USA): Permission to copy (for users in the U.S.A.) is available from Copyright Clearance Center, http://www.copyright.com, email:info@copyright.com. Specific written permission must be obtained for republication; contact the nearest Cambridge University Press office.

\section{NOTES TO CONTRIBUTORS}

The Journal of Policy History provides an interdisciplinary forum for scholars concerned with the application of historical perspectives to public policy studies. The journal aims to encourage research into the formation and development of public policy while encouraging the application of diverse methods and theories to public policy and their politics within a historical perspective. In addition to social scientists and historians, the journal seeks to inform policy makers through a historical approach to public policy.

The Journal of Policy History is intended to give voice to scholars interested in understanding public policies and their development through historical inquiry and interpretation. The journal publishes historical studies of specific policy areas and policy institutions, and explores continuities and shifts in policy over time. The journal encourages interdisciplinary research into the origins and development of public policy in the United States and other countries. Comparative historical approaches to the development of public policies are also welcomed.

Manuscripts should be typed and double-spaced with end notes following the text and generally should not exceed 8,000 words. Please follow the Chicago Manual of Style for citation format. Manuscripts will be reviewed anonymously, and authors' names, including positions, addresses, and phone numbers, should appear only on the title page. Your submission should include the following: Title page, a copy of the manuscript, an abstract not exceeding 150 words, and a biographical statement not exceeding 50 words. Submit contribution online at http://mc.manuscriptcentral.com/jpolhist. Log in and follow directions given on the site. Send correspondence to the Managing Editor, Journal of Policy History, Arizona State University, 975 S. Myrtle Avenue, PO Box 874302, Tempe, AZ 85287-4302. Visit the journal online at http://jph.asu.edu and www.cambridge.org/jph or email the journal at jpolhist@asu.edu. 